\title{
Panel Analysis on the Effect of Government Expenditure on Education and Health Sector against Poverty Numbers in Aceh 2010-2015
}

\author{
Mahadi Bahtera*, Said Muhammad, Nazamuddin, Abd.Jamal \\ Economics and Business Faculty of Syiah Kuala University, Indonesia \\ SMK- SMTI Banda Aceh Pusdiklat Kementerian Perindustrian RI
}

\begin{abstract}
The purpose of this research is to know the effect of government expenditure on education and health sector, the difference of districts with the city and the difference of parent regions to the poverty rate in Aceh Province. The method used in this study is the analysis with secondary data period 2010-2015. The Chow test yields the conclusion that the exact model used is the Common Effect Model. The estimation results indicate that the education budget, the urban area significantly influences the poverty rate, while the health budget and the district / city expansion have no effect on the poverty reduction. The simulation results concluded that if the education budget is budgeted 20 percent of the total Regional Revenue and Expenditure Budget (APBD) and the health budget is realized by 10 percent of the total APBD budget it will be able to reduce poverty in Aceh Province on average by 0.55 percent per year. Regency / municipality governments are expected to realize the education budget of $20 \%$ of APBD in accordance with Law no. 20 of 2003 article 49 paragraph 1 of the National Education System and the health budget of $10 \%$ of APBD in accordance with Law No.36 of 2009 article 171 paragraph 2 on Health.
\end{abstract}

Keywords: Poverty, Education Budget, Health Budget, Dummy Regencies /districts and dummy areas of expansion / parent

\section{Introduktion}

Aceh province is one of the regions with verynlarge npencapita spending pothein

education and health but in fact until now that tracen Propince is the kitghest province of poverty level in

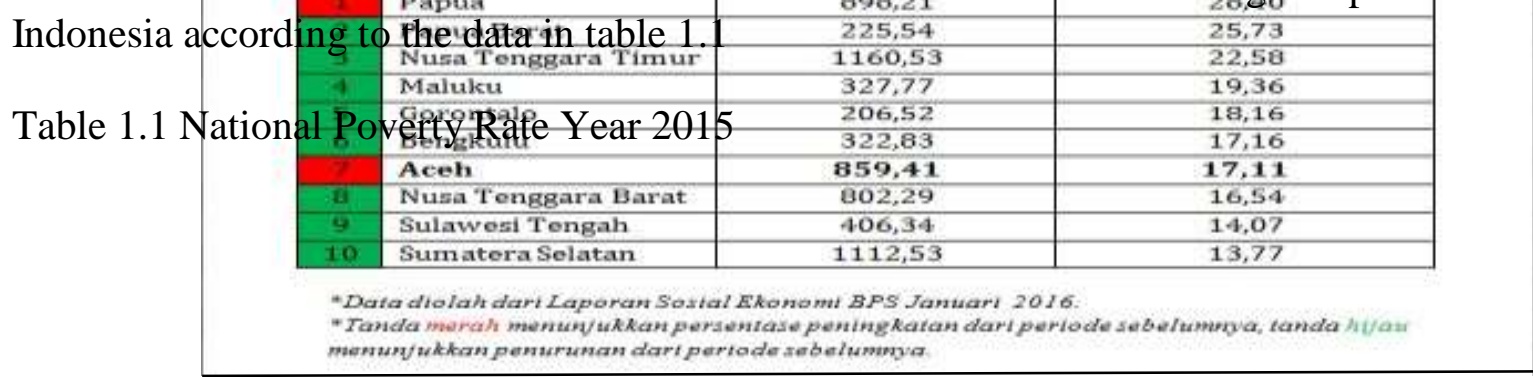

source : research data (2016) Aceh ranks seventh in the poorest province of Indonesia, below Nusa Tenggara Barat (16.54 percent). The three provinces with the highest poverty level by the end of 2015 are Papua 28.40 percent, West Papua 25.73 percent and NTT 22.58 percent respectively and Aceh's poverty is still far above the national average (11.13 percent). Compared to the tens of billions of APBA funds flowing into Aceh each year, the abundance of the budget still has not had a positive impact on 
poverty reduction, including unemployment which is one of the causes of poverty. A study by Omari \& Muturi (2016) on the impact of sectoral government spending on poverty levels concludes that there is a stable long-term relationship between poverty levels and government spending, health spending has an influence on poverty rates while education budgets are not as significant as affecting poverty. Research conducted in Papua Province with panel data on the effect of government budget on poverty by Marna (2015) concluded that education budget and health budget are the main factors influencing poverty reduction. However, it is not always the government spending on education and health budgets affecting poverty as Odior's research findings (2014) conclude that reallocating government spending to the education sector is crucial in determining economic growth and poverty reduction in Nigeria.

The division of the region in Aceh Province which originally amounted to 10 districts / cities until 2015 has become 23 districts / municipalities is a policy undertaken by the Aceh government in accordance with regional autonomy and fiscal decentralization which began on 1 January 2001 through the enactment of Law No.22 in 1999 as revised by Law no. 23 of 2014 on the government of Aceh which aims to increase the welfare of the community.

This research will analyze more about the difference of budget influence on the poverty rate in the 17 (seventeen) regency groups and 6 urban areas, 13 (thirteen) regions of areas of expansion and 10 (ten) parent regions, expansion areas (cities), (kabupaten), in Aceh Province using data from 2010-2015.

Based on the background that has been described above, it can be formulated problem formulation as follows:

Are government expenditures in the education and health budget, dummy districts and dummies Expansion of health effects simultaneously on poverty reduction in Aceh Province How to estimate poverty reduction by using education budget of

$20 \%$ of APBD in districts / cities in Aceh Province How to estimate poverty reduction by using health budget $20 \%$ of APBD in districts / cities in Aceh Province.

The general objective of this study was to determine the effect of education and health budget, types of district / municipality governments and parent regions in each district / city to poverty rate and specifically to analyze:

1. Effect of education and health budget on poverty reduction in districts / cities

2. Effect of type of district / city government on poverty rate in Aceh Province

3. Effect of regional expansion on poverty rate in districts / municipalities in Aceh

Province.

\section{Literature Review}

\section{a. Aceh Revenue and Expenditure Budget (APBA)}

The Regional Revenue and Expenditure Budget (APBD) in a special case in Aceh Province referred to as APBA is a regional government work plan that covers all revenues and expenditures (expenditures) of local governments, both provinces and districts in order to achieve targets development within a period of one year expressed in units of money and approved by the DPRA.

Harrod-Domar said that various government spending will have a positive impact on economic growth. Harrod-Domar combines both the supply-side and demand- side sides. The main aspect is the role of investment that positively impacts through multiplier effects on aggregate demand and aggregate supply through influence in production capacity. Investment can increase the capacity of capital goods and to enhance the overall expenditure of society. In other words to add agregate shopping

\section{b. Investment Human capital}

Forms of human capital investment, especially education is no less important with physical capital investment to achieve long-term economic success of a country, (Mankiw, 2003). Because human capital investment will produce much more productive and skilled labor and skilled workers, because with the level of education and training they gain are better able to perform tasks on a wider and more quality scale than less-educated and skilled workers. 
Investments in human capital in education such as in education to a higher level will have the opportunity to fill the job position formation at a higher level. Because the tasks and responsibilities are increasingly greater so that the compensation of rewards will also be worth the higher income rewards as well.

\section{c.Relationship of Variable of Capital Expenditure with Variable Level of Education}

Government expenditure in capital expenditure allocation aims to increase the acceleration of development, especially to support the life of the community such as reducing the non-school population, increasing the level of community education to higher levels and providing the necessary advice and infrastructure for continuous quality improvement. Large financing to build strategic sectors such as education will be the government's concern in encouraging regional economic development. The success of this human resource investment is largely dependent on the role of the government, because human resource development requires a considerable amount of funds and is long term. The field of education is a very strategic area in development so it is the only field that is regulated and set in the Constitution of the State. The amendment of the 1945 Constitution to article 31, paragraph 3 states that the state prioritizes the education budget of at least twenty percent $(20 \%)$ of the state revenue and expenditure budget and from the regional income and expenditure budget to meet the needs and implementation of national education.

\section{d. Relationship between Public Expenditure and Poverty.}

The problem of poverty is synonymous with inadequate public incomes, should always be a priority in the development of a country. According to Novianto (2003), the main essence of the problem of poverty is the issue of accessibility. Accessibility means the ability of a person or group of people in a society to be able to achieve or gain a desire to get the basic needs that it deserves as a citizen. Public investment in education and health will provide educational opportunities and health services more equitable to the community so that healthy human resources (HR) reliable to be more and more.

\section{e. Expansion Area / Region}

As outlined in the Elucidation of Law No.32 / 2004 on Regional Government, it is emphasized that through broad autonomy it contains several principles of expansion policy in its rules need to know namely; first, the purpose of forming, expanding, deleting and merging the regions is to improve the welfare of the people through enhancing the area of competitiveness by taking into account the principles of democracy, the acceleration of the regional economy, the acceleration of regional potential management, the enhancement of equality and order, and the enhancement of relations between regions and centers.

\subsection{Theoretical Thinking Framework}

The aim of the development is to expand many options especially in terms of income, education and health in order to achieve a better standard of living. Dritsakis and Adamopoulus (2004) in his research proved that state expenditure significantly affects economic growth, if the economy increases then the absorption of labor force will also increase so that the number of unemployment can be reduced and most likely can overcome the problem of poverty in a region. Schick (1998) mentions that one of the tasks of the government is to distribute resources on the basis of the effectiveness of public service programs and programs.Furthermore, the area of regionalization since the existence of the regional autonomy law in Aceh Province has increased from 10 districts to 23 districts and currently more than the parent regions and the estimates will be analyzed based on the poverty incidence ratio for 18 districts and 5 cities, 3 regions of Expansion Area / Region (cities) and 10 Expansion Area / Region (districts), 8 parent regions (districts) and 2 parent regions (cities) in Aceh Province.

\section{Figure 2.1 Framework for Thinking}




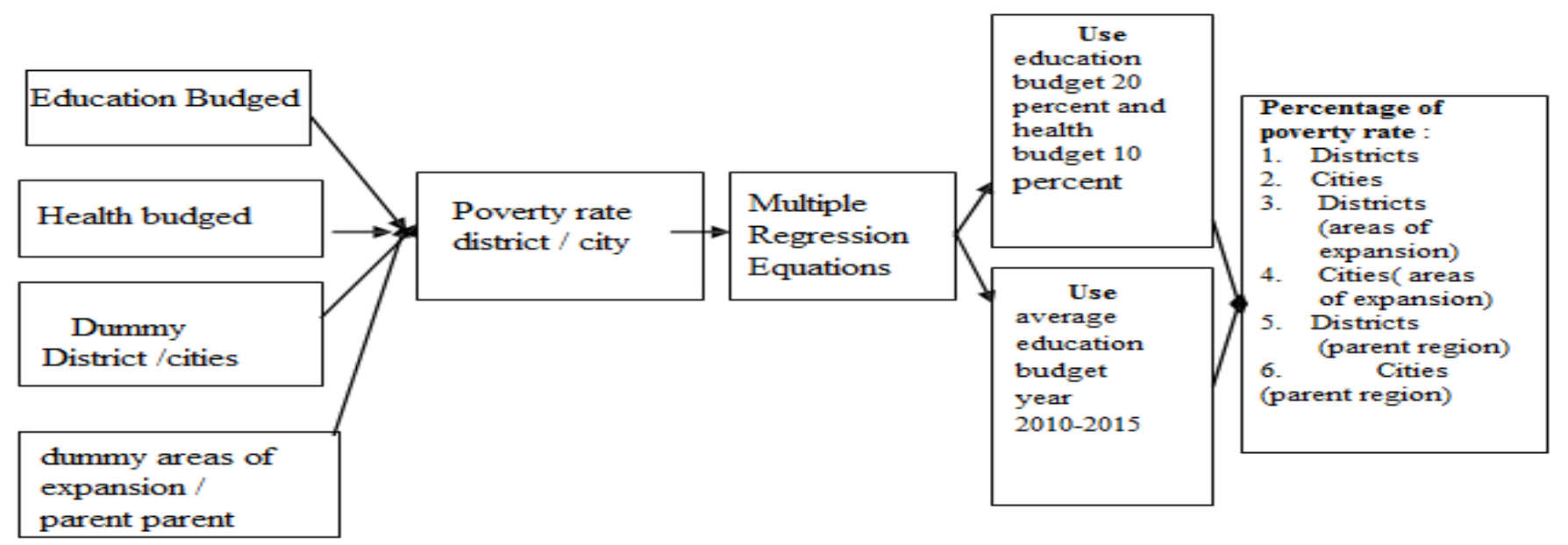

\subsection{Hipotesis}

Based on theories and the results of the study and the empirical findings described earlier, several hypotheses are formulated as follows:

H1 : Government spending on education budget,health budget, district / city dummy and dummy of areas of expansion / parent influence simultaneously to the reduction of poverty rate in districts / cities in Aceh Province

$\mathrm{H} 2$ : Government spending on the education sector is influential to the decrease of poverty rate in regencies/municipalities Aceh Province.

H3 : Government spending on the health sector is influential to the decrease of poverty rate in regencies/municipalities in Aceh Province.

H4 : Dummy District affects the numbers poverty in Aceh Province

H5 : Dummy Areas of expansion affects the decrease in number Poverty in Aceh Province.

\section{Research Methods a. Research variable}

The variables used in this study consist of dependent variable (bound) and independent variable (free). The dependent variable is the type of variable that is described or influenced by the independent variable, whereas the independent variable is the type of variable that explains or influences another variable. Dependent variable used in this research is Poverty Numbers (KMK), whereas for independent variable used in this research is government budget of education, health budget, dummy of area of expansion / parent and dummy daaerah regency / city of poverty.

\section{b.Operational Definition of Variables}

Variables used in this study include the dependent variable and independent variables. Variables of regional expenditure in the form of education expenditure, health spending, dummy regency / city and dummy of areas of expansion / parent are independent variables. While the variable poverty rate in the form of percentage $(\%)$ indicating the number of poor people is dependent variable. The operational definitions of these variables are as follows:

1). Government expenditure on education (PPD), is the amount of realization of district / city government expenditure in Aceh Province which is calculated in thousand thousand units for 2010-2015 period.

2)Health expenditure (KES) is the amount of realization of local government expenditure of districts / municipalities in Aceh Province which is calculated in thousand rupiah units for 2010-2015 period.

3). Poverty (KMK) is a condition of inability to meet basic needs. In this study, the data used is the poverty rate in 23 districts / cities in Aceh Province in 2010 -

2015 (in percent)

4). Dummi area of areas of expansion $=1$ parent region $=0$

5) Dummi city is $=1$ and County is $=0$ 


\section{c. Types and Data Sources}

This research uses multiple regression approach in the form of panel data by using secondary data. The data analyzed are data sourced from APBD reports of local government districts obtained from APBD Realization Report of fiscal year 2010 to 2015 which sourced from Central Bureau of Statistics (BPS) of Aceh Province.

\section{d. Data analysis method}

Through panel data analysis, different individual behaviors over a period of time can be captured to obtain estimation parameters. Specifications of panel data regression models containing individual-specific effects are as follows:

$y i t=\alpha i+\beta x i t+\varepsilon i t$ persamaan 3.1

where $\mathrm{y}$ it and $\mathrm{x}_{\mathrm{it}}$ are respectively independent variable variables for each individual $\mathrm{i}$ in period $\mathrm{t}$ where $\mathrm{i}=1,2, \ldots, \mathrm{N}$ and $\mathrm{t}=1,2, \ldots, \mathrm{T}$. $\varepsilon_{\mathrm{it}}$ is an error term on the panel data regression model. In $\mathrm{x}$ it there is as much as $\mathrm{K}$ slope (excluding intersept) indicating the number of free variables used in the model. $\alpha$ i are

individual effects that can be of constant value throughout the period $t$ or even vary for each i-th person. From the model design that has been described previously, then the model to be used in this research is formulated as follows:

$\mathrm{LnKMK}_{\mathrm{it}} \quad \alpha_{0}+\alpha_{1} \mathrm{LnPDD}_{\mathrm{it}}+\alpha_{2} \mathrm{LnKES}_{\mathrm{it}}+\alpha_{3} \mathrm{D} 1_{\mathrm{it}}+\alpha_{4} \mathrm{D} 2_{\mathrm{it}}+\mathrm{u}_{\mathrm{it}}$

KMK : District Poverty Rate in Aceh Province

PPD : District government education expenditure / city in Aceh

Province

KES : District government health expenditure in Aceh Province.

$\alpha_{0} \quad$ : intersep

$\alpha_{1,} \alpha_{2,} \alpha_{3,} \alpha_{4}:$ regression coefficient of independent variables $u_{i t} \quad:$ component error at time $\mathrm{t}$ for unit cross section $\mathrm{i}$

I $\quad: 1,2,3, \ldots, 23$ (district / city cross-section data) at Province of

Aceh)

$\mathrm{T} \quad: \quad 1,2, \ldots($ time-series data, 2010-2015)

$\mathrm{D}_{1 \text { it }} \quad$ : Dummy (dummy areas of expansion / parent ), areas of

$($ expansion $=1$, Parent $=0)$

$\mathrm{D}_{2 \mathrm{it}} \quad$ : Dummy (City / Regency), City $=1$, Regency $=0$

\section{Research and Discussion Result}

\subsection{Research}

This chapter consists of several sections that will explain more about the analysis and discussion of the results of testing the research hypothesis.

\section{a. Heteroscedasticity Test}

In this study the assumption of heteroscedasticity was tested using Breusch-

Pagan-Godfrey Test (BPG). Test results provide output in Table 4.1

Tabel 4.1 Uji Breusch-Godfrey

\begin{tabular}{|l|l|l|l|}
\hline Test & Statistic & d.f. & Prob. \\
\hline Breusch-Pagan LM & 452.2790 & 253 & 0.0510 \\
\hline Pesaran scaled LM & 7.836556 & & 0.0600 \\
\hline Pesaran CD & 9.522620 & & 0.0000 \\
\hline
\end{tabular}

Source: BPS (result of the data) 
The heteroscedasticity test using the Breusch-Pagan-Godfrey test produced prob values. 0.0510 . This value is greater than alpha $0.05(5 \%)$ which means that the model has no heteroscedasticity problem.

\section{b. Multicolinearity Test}

If the correlation coefficient between each independent variable is greater than 0.8

means multicollonearity occurs in the model and the data such as table 4.2

\section{Tabel 4.2 Multicolinearity Test}

\begin{tabular}{|l|l|l|l|l|l|}
\hline & $\begin{array}{l}\text { Regency/ } \\
\text { city }\end{array}$ & Poverty & Healthy & $\begin{array}{l}\text { areas } \\
\text { of }\end{array}$ & Education \\
\hline $\begin{array}{l}\text { Regency } \\
\text { /city }\end{array}$ & 1.00000 & -0.440615 & -0.238824 & -0.462250 & -0.139339 \\
\hline Poverty & & 1.000000 & -0.174539 & 0.304783 & -0.326481 \\
\hline Healthy & & & 1.000000 & 0.095240 & 0.750913 \\
\hline $\begin{array}{l}\text { areas of } \\
\text { expansion }\end{array}$ & & & & & \\
\hline Education & & & & 1.000000 & 0.067957 \\
\hline
\end{tabular}

Source: BPS (result of the data)

From multicolonierity test according to table 4.2 all coofesian independent variables smaller than 0.8 this shows that there is no multicollonearity in regression model, after testing the classical assumption for regression is fulfilled, the next step is to select the best data panel test method.

\section{c. Testing Panel Data}

The test results using the Common effect model this is because the use of dummy variables causes a singular matrix (inverse matrix $\mathrm{X}^{\prime} \mathrm{X}$ is zero).

To solve this singular matrix problem then the solution is to use the Model Pool (the same constant of each observation). Sanjoyo (2015) states that in order to interpret the effect of dummy on dependent variable, the correct model is Pool or Common effect and does not need to test Chow test because in Fixed Effect model will be singular matrix.

Table. 4.3 Processing with Common Effect Model

\begin{tabular}{|c|c|c|c|c|}
\hline Variable & Coefficient & Std. Error & t-Statistic & Prob. \\
\hline $\bar{C}$ & 6.325845 & 0.634404 & 9.971319 & 0.0000 \\
\hline LOG(Education?) & -0.165583 & 0.044220 & -3.744543 & 0.0003 \\
\hline LOG(Healthy?) & -0.012382 & 0.049541 & -0.249940 & 0.8030 \\
\hline Regency/city & -0.357549 & 0.041804 & -8.552899 & 0.0000 \\
\hline Regency /city? & 0.037645 & 0.035920 & 1.048013 & 0.2965 \\
\hline R-squared & 0.437577 & Mean dependent var & & 2.895890 \\
\hline Adjusted R-squared & 0.420662 & S.D. dependent var & & 0.252610 \\
\hline S.E. of regression & 0.192272 & Akaike info criterion & & -0.424251 \\
\hline Sum squared resid & 4.916821 & Schwarz criterion & & -0.318191 \\
\hline Log likelihood & 34.27330 & Hannan-Quinn criter. & & -0.381151 \\
\hline F-statistic & 25.86917 & Durbin-Watson stat & & 0.230516 \\
\hline Prob(F-statistic) & 0.000000 & & & \\
\hline
\end{tabular}

Source: BPS (result of the data)

\section{d. Regression and Hypothesis Estimation Results \\ 1). Printing Test (F Test)}

Results Data processing in accordance with table 4.7 note that the value of F statistics of 0.000 is with $\mathrm{p}$ value smaller than the value of alpha testing $(0.0000<0.05)$. Thus, Hypothesis $1(\mathrm{H} 1)$ concludes with the conclusion that the variables of expenditure in the education sector, health expenditure, dummy districts and dummy regencies / cities as a whole are able to explain variability of poverty rate variable equal to Adjusted R-squared $=33.7 \%$. While the rest of $66.3 \%$ is explained by other variables that are not discussed in this study. 


\section{2) Partial Testing ( $\mathrm{t}$-test)}

\section{The Effect of Education Budget on the Poverty Rate}

From the test results of the regression model coefficients in the table above, the $\mathrm{p}$ -

value value for government expenditure variable in education field shows a value of 0,000 which means less than $0.05(0.000<0.05)$. This result concludes that Hypothesis $(\mathrm{H} \neg 2)$ is accepted which means that "Education budget affects poverty in Aceh Province"

\section{a) Effect of Health Budget on Poverty Numbers}

From the test results of the regression model coefficients in the table above,

the p-value for the Government Health Expenditure variable shows the Prob value. 0.803 which means greater than $0.05(0.000<0.05)$. These results conclude that Hypothesis $(\mathrm{H} \neg 3)$ is rejected which means that:

"Health budget does not affect poverty rate in Aceh Province.

\section{b). Influence Dummy District / City terahadap poverty figures}

From the result of regression model coefficient test in the above table, p-value for dummy variable of regency / city shows Prob value. 0.000 which means less than

$0.05(0.000<0.05)$. This result concludes that Hypothesis $(\mathrm{H} \neg 4)$ is accepted which means that: "District dummy variables affect poverty rate in Aceh Province

\section{c) Influence of Dummy of Regency / City on Poverty Rate}

From the test results of the regression model coefficients in the table above, the pvalue for the dummy variable of the Expansion / Parent region shows the Prob value. 0.2965 which means greater than $0.05(0.2965<0.05)$. This result concludes that Hypothesis (H4) is rejected, which means that: "Dummy variation of areas of expansion / mother does not affect poverty rate in Aceh Province.

\subsection{Discussion of Research Results}

The result of data processing of regression equation for poverty rate, regression equation model is:

$\operatorname{Ln}(K M K)=6,32-0,165 \ln ($ PDD $)-0,0123 \operatorname{Ln}($ Kes $)-0,35$ dummy $($ kabkota $)+0,037$ dummy areas of expansion $\quad(t=-3,74)$ $(t=-0,249) \quad(t=-8,55)$ $(\mathbf{t}=\mathbf{1 , 0 4 8 )}$

\section{a. Analysis and Implications of the Effect of Education Budget on Poverty Numbers}

Based on the results of the data by testing the first hypothesis that proves that the educational budget variable influential siginfikan to variable poverty rate. Table 4.3 shows that education budget has negative and significant effect to poverty rate with p-value coefficient 0,165 . From the output of the equation, it can be interpreted that in all of Aceh Province if there is an increase of education budget by 1 percent there will be a decrease of poverty figure of 0.165 percent. The results of this study are consistent with the findings of several researchers described in the previous chapter, such as Omari (2016), Ruseva (2015), Odior (2014), Marisa Hidalg (2014), Ruseva, et al (2015) Poverty rate.

\section{b)Analysis and Implications The Influence of Health Budget on Poverty}

Table 4.3 shows that the p-value coefficient is 0.8030 . From the output of the equation, it can be interpreted that the health budget does not affect the decrease of poverty rate. These findings contradict the results of the Sepulveda (2010) study, which states that government spending on basic health and basic education has an influence on the poor so as to be seen as pro-poor spending, as well as Wahyudi's (2011) lowered the poverty index by $0.067 \%$ of poverty, while education spending reduced the poverty index by $0.304 \%$.

\section{c)Analysis and Implications Influence of Regency / Municipality Variables on Poverty Rate}

Table 4.3 shows that the type of region has significant and significant effect on poverty with p-value coefficient 0.000 . From the output of the equation, it can be interpreted that the type of regency / city has an effect on the poverty rate in Aceh Province in terms of dummy determination of city $=1$ and dummy regency $=0$ indicates that the city area has an effect on the decreasing of poverty. With co- ordination of 0.35 indicating that every $1 \%$ increase in budget in $\mathrm{kab} /$ kota area will decrease -0.35 percent poverty rate and urban area can decrease poverty greater than districts. This finding is consistent with the findings of Ermasari (2009) Ermasari (2009) who conducted a study in Java-Madura with the conclusion that the poverty rate in the municipality is lower in percentage than the districts. 


\section{d) Analysis and Implication of Influence of Areas of expansion Region on Poverty}

Based on the results of the data by testing the fourth hypothesis does not prove that the variables of the areas of expansion have significant effect on the poverty rate, it is in accordance with the above table that $\mathrm{p}$-value is 0.296 so the conclusion is that the firing does not affect the decrease of poverty rate. This finding is very different from the hopes and objectives of areas of expansion because initially the concept of division of the region itself by Tiebout (1956) which states that the expansion of the region is analogous to a model of perfectly competitive economy where local government has the power to maintain low tax rates, efficient, and permit each individual community to express its preference for each type of service from different levels of government with "vote with their feet.

\section{e) Interpretation and Prediction of Research Results}

1). With the estimation of the multiple linear equations of the results of this study, if the realization of education budget $20 \%$ of total APBD and the realization of health budget $10 \%$ of total APBD then the figures are summed up as follows:

1) District districts include South Aceh, Southeast Aceh, East Aceh, Central Aceh, Pidie, Aceh Utara, Aceh Barat, Aceh Besar, Aceh Singkel, Aceh Jaya, Aceh Tamiang, Bener Meriah, Nagan Raya, Siumelu, Bireun, Pidie Jaya, Abdya, Gayo Lues when allocated education budget 20 percent from APBD and Health Budget 10 percent from APBD then average can reduce poverty by 0,31 percent.

2) The City area consisting of Banda Aceh City, Sabang City, Lhoekseumawe City, Langsa City, Subulussalam City if allocated 20 percent of education budget from APBD and Health Budget 10 percent from APBD then the average can reduce poverty by 1.43 percent.

3)Main Areas: South Aceh, Southeast Aceh, East Aceh, Central Aceh, Pidie, Aceh Utara, Aceh Barat, Aceh Besar, Banda Aceh City, Sabang City if allocated education budget 20 percent of APBD and health budget 10 percent of APBD the district average can reduce the poverty rate by 0.439 percent.

4) Aceh Jaya, Aceh Tamiang, Bener Meriah, Nagan Raya, Siumelu, Bireun, Pidie Jaya, Abdya, Gayo Lues, Langsa City, Lhoekseumawe City, Subulussalam City if allocated education budget 20 percent of APBD and health budget 10 percent of APBD then the average district can reduce the poverty rate by 0.67 percent.

5) The municipality is Banda Aceh, Sabang when allocated 20 percent of education budget from APBD and health budget 10 percent from APBD then average can reduce poverty rate equal to 1,28 percent.

6) The area of Areas of expansion (city ) is Langsa City, Lhoekseumawe City, Subulususalam City if allocated education budget 20 percent from APBD and Health Budget 10 percent from APBD then it can reduce the poverty rate by 1.53

percent.

7) The area of Areas of expansion (District): Aceh Singkel, Aceh Jaya, Aceh Tamiang, Bener Meriah, Nagan Raya, Siumelu, Bireun, Pidie Jaya, Abdya, Gayo Lues when allocated education budget 20 percent of APBD and Health Budget 10 percent of APBD then can reduce poverty by 0.43 percent.

From the above data, using substitution of multiple linear regression results if the district / city governments comply with the Education Law and Health Law by deliberating $20 \%$ of the APBD for education and $10 \%$ of the APBD for the largest health budget can decrease the number is the area of Areas of expansion city) of

1.53 percent and the lowest is the parent region (district) of 0.2 percent. This difference is due to the allocated and realized budget for health budget in Aceh Province is not sufficient realization in the period 2010-2015 on average only 5.35 percent.

\subsection{Prediction of Health Budget 10 percent of total APBD}

The follow-up findings of this study, with prediction of health budget increased by $10 \%$ from APBD, the health budget will have a significant effect on the decreasing of poverty rate and to convince this finding, it is done by comparison process with Common Effect model test, it can be concluded that " significant to poverty "with the conclusion that any $1 \%$ increase in the health budget will have an effect on reducing the poverty rate by 0.09 percent. So the conclusion for this study is that health budget has no significant effect on the poverty rate in Aceh because the budget allocated by the district government is still very low, which is around 5.4 percent of the total APBD budget in Aceh. 


\section{Conclusions And Policy Implications \\ 5.1 Conclusions}

Based on the results of data analysis and discussion that has been explained then can be drawn conclusion as follows:

1. Government expenditures in the education sector, health sector, district / city varianiabel and regional variable of areas of expansion / region of Parent have an effect on the poverty rate together and can explain the effect of poverty rate $33,7 \%$.

2. Government spending in education sector has a negative and significant effect on poverty rate in Aceh Province Health sector government expenditure has a negative relationship to poverty but has no significant effect, this is because very low health budget is allocated by district / municipality governments in Aceh Province.

3. Variables The districts / municipalities have a negative and significant effect on the poverty rate in Aceh Province, the city area is lower in poverty than the district.

4. The areas of expansion did not significantly influence the poverty rate in the province of Aceh, the higher the poverty rate compared to the parent regions.

5. The results of the prediction for realizing the health budget of $10 \%$ of the total APBD during the period 2010-2015, the health budget has a significant effect on the reduction of poverty in all regencies / municipalities in Aceh Province.

\section{b.Policy Implications.}

1.To accelerate poverty reduction, the allocation of education budget must be realized at least 20 percent of APBD by district / city governments, especially areas with the highest poverty rate in Aceh Province.

2. Regions with high poverty rates are expected by the regional government to allocate a minimum health budget of 10 percent of APBD each year by adjusting to the budget increase perkapitanya.

3. Because the division will increase the poverty of the community, the regions / regions of the government and the legislature will need to study more detail about the expansion of regions / regions.

4. To reduce poverty in Aceh Province it is expected that district / city governments can comply with the mandate of Law no. 20 of 2003 on National Education System Article 49 concerning education budget allocation of at least 20 percent of APBD and Law No. 36 Year 2009 article 171 paragraph 1 and 2 that the allocation of health budget at least 10 percent of the APBD.

\section{References}

1. Abdul Hakim. 2001. Ekonomi Pembangunan. UII Press. Yogyakarta.

2. Arsyad, Lincolin, 2010. Ekonomi Pembangunan, UPP STIM YKPN Yogyakarta. Badan Penerbit Universitas Diponegoro, Semarang.

3. Barro, Robert J., May 1991. Economic Growth and The Asian Financial Crisis, Quarterly Journal of Economics, Vol. 106, No. 2. , pp. 407-443. based Economy : The Case of Yemen. Revised: January

4. Bellante, Don dan Mark Janson 2006. Ekonomi Ketenagakerjaan, Jakarta.

5. Blejer, M., Khan, M., 1984. Government Policy and Private Investment in Developing Countries. IMF Staff Papers, Vol. 31, No. 2, pp. 379-403. BPS. 2009. Data dan Informasi Kemiskinan

6. . 2009. Indikator Utama Sosial, Politik dan Keamanan Provinsi Aceh 2008.

7. . Aceh Dalam Angka Tahun 2000 s.d 2015

8. . Statistik Keuangan Daerah Kabupaten dan Kota Berbagai Publikasi Brata, Aloysis Gunandi, 2005. Investasi sektor Publik lokal, Pembangunan Manusida dan Kemiskinan, Lembaga Penelitian Universitas Atmajaya. Yogyakarta.

9. Dritsakis, Nikolas dan Adamopoulus, Antonis. (2004). A Causal Relationship Between Government Spending and Economic Development: An mpirical Examination of the Greek Economy. Journal Applied Economics.

10. Ermasari, Ade, 2009. Dinamika Kemiskinan Di Jawa-Madura Menurut Kabupaten Kota Tahun $2002-$ 2007 Vol 23 No. 21, Universitas Gajdah Mada, Yogyakarta 
11. Fan, Shenggen. 2000. How Does Public Spending Affect Growth and Poverty /The Experience of China. Paper submitted to 2nd annual Global development Network Confrence. Tokyo, Japan. for Colombia. Preliminary Draft.

12. Fischer MM, Wang J. 2011. Spatial Data Analysis: Models, Methods and Techniques. London: Springer Heidelberg Dordrecht.

13. Ghozali, Imam, 2009. Aplikasi Analisis Multivariate Dengan Program SPSS, Edisi Keempat, Penerbit Universitas Diponegoro.

14. Gujarati, N.Damodar. (2003). Basic Economertis, fourth edition. New York: McGraw-Hill

15. Hajibabaei, Hamidreza and Alimohammad Ahmadi, 2014. Government Size and Human Development: Quadratic Regression Approach, International Journal of Academic research in Business and Social Sciences Vol. 4, No.4.

16. Hamzah, Ardi. (2007). Pengaruh Belanja Dan Pendapatan Terhadap Pertumbuhan

17. Ekonomi, Kemiskinan, Dan Pengangguran (Studi Pada APBN 1999-2006).

18. Harijono, Gatot Setio dan I Made Suyana Utama, 2013. Analisis Pengaruh pengeluaran Pemerintah dan Investasi terhadap Kesempatan Kerja melalui Pertumbuhan Ekonomi, Fakultas Ekonomi, Universitas Udayana Bali.

19. Hill, R. C., Griffiths, W. E., Lim, G. C., Berenson, M.L. (2011). Principles of Econometrics. 4th Edition. United States: John Wiley \& Sons, Inc. Ilhamsyah, Muhammad Siregar, 2012. Analisis Realisasi Anggaran Penpadatan

20. Dan Belanja Daerah Aceh Terhadap Pertumbuhan Ekonomi, Pengangguran, Dan Kemiskinan, Universitas Syiah Kuala.

21. Indra, Sukma, 2012. Pengaruh Investasi Pemerintah terhadap Pertumbuhan Ekonomi dan Penyerapan Tenaga Kerja serta Disparitas antar Daerah dan Kesejahteraan Masyarakat di Kabupaten/Kota di Provinsi Kalimantan Barat. Disertasi, Universitas Airlangga

22. Irawan dan M. Suparmoko, 2002. Ekonomika Pembangunan, Edisi Keenam, BPFE, Yogyakarta.

23. Iskana, Ida. (2009). Pengaruh Belanja dan Pendapatan Terhadap Pertumbuhan Ekonomi, Kemiskinan, Dan Pengangguran. SKRIPSI, tidak dipublikasikan, Malang, Fakultas Ekonomi Universitas Islam Malang.

24. Ismawanto. (2009). Ekonomi 3: Untuk SMA dan MA Kelas XII, Jakarta: Pusat perbukuan, Departemen Pendidikan Nasional.

25. Jhingan, ML.2000. Ekonomi Pembangunan dan Perencanaan. Edisi Pertama. Raja grafindo Persada. Jakarta.

26. Jonaidi, Arius. (2012). Analisis Pertumbuhan Ekonomi dan Kemiskinan. Jurnal Kajian Ekonomi, Volume 1, Nomor 1.

27. Jones, Patricia, 2001. Are Educated Really Workers More Productive Journal of Development Economics, No.64: Page 57-79.

28. Kaplale, Raihana, 2012. Factor Inluencing The Level Of Poverty In Ambon City. Agribisnis Faperta Unpatti Ambon

29. Kepmendagri Nomor 29 Tahun 2002 tentang Struktur Anggaran Pendapatan dan Belanja Daerah (APBD).

30. Keynes, J. M. 1936. The General Theory of Employment, Interest and Money.New York: Harcourt Brace.

31. Kuncoro, Mudrajad. (2004). Otonomi dan Pembangunan Daerah, Jakarta. Penerbit: Erlanga

32. Kurniawan, A.L. (2008) "Analisis Pengaruh Pengeluaran Pemerintah terhadap Pertumbuhan Produk Domestik Regional Bruto Kabupaten Ponorogo Tahun 1993- 2006”. Skirpisi Unair, Tidak Dipublikasikan.

33. Lembang, Hendricus, 2015. The Effect Of Goverment Expenditures And Banking Credit Expansion On The Performance Of Human Resource Development In Papua

34. Liao, Jiangqun dan Xiaoyan Liu, 2012. Risk and Consumer Debt Behaviors in China, Journal, Social Behavior and Personality, Tsinghua University and Peking University, China.

35. Mahmudi. 2007. Manajemen Kinerja Sektor Publik. UPP STIM YKPN.Yogyakarta.

36. Mankiw, N.Gregory. (2006). Principles Of Economics Pengantar Ekonomi

37. Makro. Edisi \Ketiga. Jakarta: Salemba Empat. 
38. Marna, 2015, Pemodelan Persamaan Struktural Pada Kasus Depedensi Spasial, Kemiskinan Di Provinsi Papua, Institut Pertanian Bogor

39. Mirza, Denni Sulistio, 2012. Pengaruh Kemiskinan, Pertumbuhan Ekonomi, dan Belanja Modal Terhadap Indeks Pembangunan Manusia di Jawa Tengah Tahun 2006-2009, Economics Development Analysis Journal,Universitas Negeri Semarang.

40. Munawwaroh, 2013. Faktor-Faktor yang Mempengaruh Sumber Daya Manusia dan Perekonomian Kabupaten/Kota di Provinsi Jambi, Jurnal Kajian Ekonomi, Juli, Vol. II No. 03.

41. Musgrave, Richard. A dan Peggy B Musgrave. 1989. Public Finance in Theory and Practise. Fifth Edition, McGraw-Hill Book, International Edition,1989.

42. M. Ruseva ,Genov D, Jekova. 2015. Impact Of Poverty On The Human Development Index In Bulgaria, University Of Plovdiv, Bulgaria

43. Novianto Dwi Wibowo. 2003. Masalah Pengentasan Kemiskinan di Indonesia: Pendekatan Hipotesis Kuznet. Buletin Pangsa. Edisi 10/IX.

44. Obi, Mikel. 2014 : Population, Education, And Poverty In Nigeria.

45. Odior O, Ernest Simeon, 2014 Government Expenditure On Education And Poverty Reduction: Implications For Achieving The Mdgs In Nigeria A Computable General Equilibrium MicroSimulation Analysis.

46. Omari V dan Willy Mutury, 2016 the Effect Of Goverment Sectoral Expenditure on Poverty Level in Kenya, volume 16 version 1, Global Jurnal Inc.

47. Prawoto, Agus, 2011. Pengantar Keuangan Publik, BPFE, Yogyakarta.

48. Putra, A, 2009 Pengaruh Pertumbuhan ekonomi terhadap Pendapatan Asli Daerah. Jurnal Logika, 7(2), 12-25. Rajawali Pers, Jakarta.

49. Rahmadanny, Bobbi Satria, 2013 Analisis Kemiskinan Aceh Universitas Syiah Kuala

50. Riani dan Pudjihardjo, 2012. Analisis Dampak Pemekaran wilayah terhadap pendapatan perkapita , kemiskinan dan ketimpangan antara wilayah di Provinsi Papua. Jurnal Bumi Lestari, Volume 12 No. 1, Februari 2012, hlm. 137 - 148

51. Romer, David, 1996. Advanced Macroeconomics, University of California, Berkeley. Rubin, Irene S. 1993. The Politic of Public Budgeting: Getting and Spending, Borrowing and Balancing, Chatam, NJ, Chatam House Publishers, Inc. Second Edition.

52. Shabri, M Abd Majid, 2014. Analisis Tingkat Pendidikan Dan Kemiskinan Di Aceh, Universtitas Syiah Kuala. Banda Aceh

53. Sadono Sukirno, 2000. Makroekonomi Modern. Raja Grafindo Persada. Jakarta. Samuelson, A.Paul. (2004). Ilmu Makro Ekonomi. Edisi Tujuh Belas. Jakarta:PT Media Global Edukasi.

54. Sanggelorang, Septiana Dkk, 2015. Pengaruh Pengeluaran Pemerintah Di Sektor Pendidikan Dan Kesehatan Terhadap Indeks Pembangunan Manusia Di Sulawesi Utara. Makasar.

55. Schick, Allen, 1998. The International Bank For Reconstruction And Development, New Zealand.

56. Sen, Amartya, 1985. Development As Capability Expansion. Harvard University

57. Siddik, Jaffar Pohan, 2015. Analisis Dmpak Pemekaran Kabupaten Labuhanbatu Utara Terhadap Perkemabangan Pembangunan Kabupaten Labuhan Batu Utara Sesuai Dengan PP No.129 Tahun 2010 Vol 6, Politika

58. Sjafrizal, 2008. Ekonomi Regional Teori dan Aplikasi, Baduose Media, Padang

59. Suryana, 2000. Ekonomi Pembangunan, Problematika dan Pendekatan.

60. Jakarta: Salemba Empat.

61. Suyatno, Thomas et al, 2003, Dasar-Dasar Perkreditan, Edisi Ketiga, Gramedia, Pustaka Utama, Jakarta.

62. Sanjoyo, 2015 Konsultasi Ekonometrika dan Pembahasannya , Jakarta media online sanjoyo.com

63. Swianiewicz, P. 2002. Consolidation or Fragmentation The Size of Local governments in Central And Eastern Europe. Local Government and Public Service Reform Initiative, Open society Institute Budapest, Budapest

64. Theil, H. 1953. Repeated Least-Squares Applied to Complete Equation Systems.

65. The Netherlands: The Hague The Central Planning Bureau 
66. Todaro , Michael P.dan Stephen C.Smith, 2011. Pembangunan Ekonomi, Jilid 1, Penerbit Erlangga, Jakarta.

67. Tri, Maryani, 2011. Analisis Indeks Pembangunan Manusia diProvinsi Jawa

68. Tengah, Tesis, UPN Veteran, Yogyakarta.

69. Utami, 2007.Pengaruh Pengeluaran Pemerintah Bidang Pendidikan dan

70. Kesehatan terhadap Indeks Pembangunan Manusia.

71. UU no 29 tahun 1999 Tentang Pemerintahan Daerah Departemen Keuangan

72. UU No 23 Tahun 2014 Tentang Pemerintah Aceh, Provinsi Aceh

73. Widodo, Ari, Waridin Dan Johanna Maria K., 2011. Analisis Pengaruh Pengeluaran Pemerintah Di Sektor Pendidikan Dan Kesehatan Terhadap Penegentasan Kemiskinan Melalui Peningkatan Pembangunan Manusia Di Provinsi Jawa Tengah

74. Winarno, Wing W. 2009. Analisis Ekonometrika dan Statistik dengan EViews.

75. Yogyakarta: UPP STIM YKPN

76. Widyastuti, Astriana, 2012. Analisis Hubungan Antara Produktivitas Pekerja dan Tingkat Pendidikan Pekerja terhadap Kesejahteraan Keluarga di Jawa Tengah Tahun 2009, Economics Development Analysis Journal, Jurusan Ekonomi Pembangunan, Fakultas Ekonomi, Universitas Negeri Semarang, Indonesia.

77. Wijaya, Farid dan Soetatwo Hadiwigeno, 1991. Lembaga-Lembaga Keuangan dan Bank, Perkembangan, Teori dan Kebijakan, BPFE, Yogyakarta. Foundation, the Princeton University Center for Migration, the Social Science Research Council Program in Applied Economics.

78. Winarti, astri, 2014. Analisis Pengaruh Pengeluaran Pemerintah Bidang Pendidikan, kemiskinan, dan PDB terhadap Indeks Pembangunan Manusia di Indonesia. Universtias Dipenogero

79. World Bank, 2001. World Development Report 2000/2001: Attacking Poverty. Wurarah, Ruly Novie, 2011. Pengaruh Belanja Modal terhadap Pertumbuhan

80. Ekonomi dan Penyerapan Tenaga Kerja serta Kesejahteraan Masyarakat di Provinsi Papua Barat, Disertasi Universitas Airlangga, Surabaya

81. Yustika, A.E 2006. Perekonomian Indonesia (deskripsi, preskripsi dan kebijakan). Malang: Banyumedia Publishing.

82. Yustika, Achmad Erani. Editor. 2008. Desentralisasi Ekonomi di Indonesia: Kajian Teoritis dan Realitas Empiris. Banyumedia. Malang.

83. Zuluaga. 1990. Different Channels of Impact of Education on Poverty: Annalysi 